\title{
Symptom cluster analysis of long COVID-19 in patients discharged from the Temporary COVID-19 Hospital in Mexico City: A longitudinal study
}

Rosa María Wong-Chew ${ }^{1}$, Edwin Xchel Rodríguez Cabrera ${ }^{2}$, Carlos Alberto Rodríguez Valdez ${ }^{2}$, Julieta Lomelín Gascón ${ }^{2,3}$, Linda Morales Juárez ${ }^{2}$, Mariana Lizbeth Rodríguez De La Cerda ${ }^{1}$, Antonio Rafael Villa Romero ${ }^{2}$, Stephanie Arce Fernández ${ }^{2}$, Mariana Serratos Fernandez ${ }^{2}$, Héctor Herrera Bello ${ }^{2}$, Lidia Moreno Castañeda ${ }^{2}$, Mónica Arboleya Avendaño ${ }^{2}$, Jesús Abraham Hernández Cruz $^{2}$, Nelson Álvarez Martínez ${ }^{2}$, Liza Fernanda Contreras ${ }^{2}$, Luis Rafael González de la Cerda ${ }^{2}$, Arturo Juárez Flores ${ }^{2}$, Luis Alberto Martínez Juarez ${ }^{3,4}$, Diego-Abelardo Álvarez-Hernández ${ }^{3,4}$, Héctor Gallardo-Rincón ${ }^{2,3^{*}}$, German Fajardo Dolci, MD ${ }^{1}$, Roberto Tapia-Conyer ${ }^{1,3}$, and Rafael Ricardo Valdez Vázquez ${ }^{2}$

${ }^{1}$ National Autonomous University of Mexico, Coyoacán, 04510 Mexico City, Mexico

${ }^{2}$ Temporary COVID-19 Hospital, Av. del Conscripto 311, Lomas de Sotelo, Hipódromo de las Américas, Miguel Hidalgo, 11200 Mexico City, Mexico

${ }^{3}$ Carlos Slim Foundation, Lago Zurich 245, Presa Falcon Building (Floor 20), Miguel Hidalgo, 11529 Mexico City, Mexico

${ }^{4}$ London School of Hygiene and Tropical Medicine, Keppel St, Bloomsbury, London WC1E 7HT, United Kingdom

\section{*Corresponding author}

Héctor Gallardo-Rincón

Lago Zurich 245, Presa Falcon Building (Floor 20), Miguel Hidalgo, 11529 Mexico City, Mexico

Tel: +5215541818180

Fax: +5215541818180

E-mail: hgallardo@fundacioncarlosslim.org

Word count, abstract: 199 (limit: 200 words)

Word count, text: 3424

Number of tables/figures: $3 / 4$

Number of supplementary files: 1 supplementary text and 2 supplementary figures 


\begin{abstract}
Recently, several reports have emerged describing the long-term consequences of COVID-19 that may affect multiple systems, suggesting its chronicity. As further research is needed, we conducted a longitudinal observational study to report the prevalence and associated risk factors of long-term health consequences of COVID-19 by symptom clusters in patients discharged from the Temporary COVID-19 Hospital (TCH) in Mexico City. Self-reported clinical symptom data were collected via telephone calls over 90 days post-discharge. Among 4670 patients discharged from the TCH, we identified 45 symptoms across eight symptom clusters (neurological; mood disorders; systemic; respiratory; musculoskeletal; ear, nose, and throat; dermatological; and gastrointestinal). We observed that the neurological, dermatological, and mood disorder symptom clusters persisted in $>30 \%$ of patients at 90 days post-discharge. Although most symptoms decreased in frequency between day 30 and 90, alopecia and the dermatological symptom cluster significantly increased $(p<0.00001)$. Women were more prone than men to develop long-term symptoms and invasive mechanical ventilation also increased the frequency of symptoms at 30-days post-discharge. Overall, we observed that symptoms often persisted regardless of disease severity. We hope these findings will help promote public health strategies that ensure equity in the access to solutions focused on the long-term consequences of COVID-19.
\end{abstract}

Key Words: Long COVID, symptom cluster, persistent symptoms, long-term, Mexico, survey 


\section{Introduction}

After more than 12 months of battling SARS-CoV-2, the global pandemic seems to be far from over, and many countries are still struggling to curb infection rates. This is despite the rapid development of several currently available vaccines and the ongoing development of numerous treatments. Current COVID-19 statistics from the World Health Organization indicate that as of 20 May 2021, over 163 million cases have been confirmed, over 3.3 million have died, and approximately 150 million individuals have recovered worldwide. ${ }^{1}$ As the pandemic evolves, a new patient category has emerged among seemingly recovered COVID-19 patients. These patients continue to present some symptoms and may even develop new symptoms past the acute stage (4 weeks) of the infection. The persistent or recurring symptomatology is referred to as post-acute COVID-19 ("long COVID") and even patients with relatively mild disease can be affected. ${ }^{2,3}$ Therefore, it is important to view COVID19 as more than just an acute disease.

Evidence is growing regarding the long-term effects of COVID-19 on patients' health; however, evidence regarding the prevalence and pattern of symptoms related to the long-term health consequences of COVID-19 is primarily based on surveys. In some preliminary reports it has been shown that 8 weeks after diagnosis, the proportion of patients with one or more persistent COVID-19 symptoms ranged from $66 \%$ to $87 \% .^{4-6}$ The symptoms are heterogeneous and include alopecia and other skin conditions (e.g., pernio), ${ }^{7}$ fatigue, dyspnoea, joint and chest pain, ${ }^{5}$ impaired pulmonary function, post-exertional malaise, cognitive dysfunction, ${ }^{8,9}$ headaches, vertigo, anosmia, ${ }^{5}$ sleep difficulties, anxiety, and depression. ${ }^{10}$ Reportedly, these long-term symptoms severely affect their quality of life ${ }^{5}$ activities of daily living and work, and in some cases, lead to significant disability. ${ }^{11}$

So far, no consensus has been reached regarding the definition of long COVID-19, although some terminology has been proposed. ${ }^{12}$ Data on persisting symptoms are still lacking and therefore there is a need for further research and long-term follow-up of patients with long COVID-19 to clarify these long-term effects and guide the development of potential management strategies to alleviate these symptoms and improve the overall health and quality of life of these patients. ${ }^{13}$ Thus, it is necessary to promote research that improves our understanding of the pathophysiology and epidemiology of the post-acute phase as well as promote public health strategies and clinical algorithms that ensure equity ${ }^{14}$ in the access to these solutions. Therefore, this study aimed to report the prevalence and associated risk factors of long-term health consequences of COVID-19 by symptom clusters in patients discharged from the Temporary COVID-19 Hospital (TCH) in Mexico City.

\section{Materials and Methods}

2.1 Study design 
This was an observational, prospective, longitudinal, single-centre study. Patients discharged from the $\mathrm{TCH}$ at the Citibanamex Convention Center in Mexico City between September 2020 and January 2021 were followed up by a telephone survey for up to 90 days. Self-reported clinical symptom data collected via telephone follow-up were analysed and summarised for 30- and 90-days post-discharge.

As part of routine clinical practice at the $\mathrm{TCH}$, all patients received an oximeter and were trained in its use at discharge from the $\mathrm{TCH}$. All patients discharged from the $\mathrm{TCH}$ underwent followup by telephone to assess their health status and recovery (Supplementary Text 1).

The Research Ethics Committee of the Faculty of Medicine of the National Autonomous University of Mexico (FM/DI/094/2020) approved the study. This study also adhered to the Declaration of Helsinki, as well as local laws and regulations. All patients provided verbal informed consent before participation in the survey.

\subsection{Patients}

Male or female patients aged $\geq 18$ years, admitted to the $\mathrm{TCH}$, with a confirmed diagnosis of COVID19 by PCR; treated, discharged, and considered to be recovered from COVID-19, who were followed up for at least 90 days since discharge from the $\mathrm{TCH}$; and who had answered at least three follow-up calls were included in this study.

Excluded patients were those who died in the hospital, had a severe underlying disease, had no telephone, denied participation in the follow-up, were unable to respond to the questionnaire, provide the necessary detailed information, or perform the required measurements (i.e., oximetry or temperature), and women who were pregnant or breastfeeding.

\subsection{Outcomes}

The main outcomes were the prevalence of the most frequently reported symptoms, by symptom clusters, that persisted or developed anew at 30- and 90-days post-discharge; the associations of symptoms at 30- and 90-days post-discharge by sex, comorbidities (diabetes, hypertension, and obesity), biomarkers, and treatment during hospitalization; and risk factors for the persistence of the most frequent symptoms at 30 - and 90-days post-discharge.

\subsection{Follow-up and data collection}

Ten follow-up calls were made to each patient during the 90-day follow-up period. Follow-up telephone calls were systematically distributed throughout the follow-up period as follows: days 1, 3, 7, 14, 21, 30, 45, 60, 75, and 90 after discharge.

During the ongoing telephone call, each patient was asked to measure their oxygen saturation and body temperature during the first 21 days post-discharge. This follow-up period of 21 days was 
designed to provide rapid access to remote assistance if necessary. Additionally, patients were asked to complete a questionnaire related to persistent COVID-19 symptoms.

The questions asked included the following: presence or absence of 45 clinical symptoms; the clinical course of reported symptoms; current health status compared with pre-COVID health status; presence of any breathing difficulties overall, at rest, or during physical exertion; and whether patients were receiving any type of pulmonary rehabilitation.

Demographic and clinical background, clinical course during the acute illness, and relevant laboratory data were obtained from the electronic medical records of the $\mathrm{TCH}$ digital health platform.

\subsection{Statistical analysis}

Owing to the nature of the study, sample size calculations were not performed. Efforts to minimise bias consisted of training the surveyors before conducting the follow-up questionnaire to minimise information bias and adjust for confounders in our multivariable analyses.

Descriptive statistics were used, with $\mathrm{n}(\%)$ for categorical variables and mean \pm standard deviation or median (interquartile range [IQR]) for continuous variables. For comparisons between groups, Chi-square or Fisher's exact test were used. The groups for comparison were 1) patients who reported a specific symptom versus those who did not and 2) males versus females.

Bivariate analysis was used to identify the characteristics associated with a specific symptom. To identify risk factors associated with persistence of COVID-19 symptoms, adjusted multiple logistic regression models were used to estimate the odds ratios (ORs) and 95\% confidence intervals $(\mathrm{Cls})$ for the association between factors including sex, age, education level, treatment with steroids, comorbidities, biomarkers, need of high flow nasal cannula (HFNC) or invasive mechanical ventilation (IMV), and occurrence of persistent symptoms.

A p-value $<0.05$ indicated statistical significance, and all tests were two-sided. The statistical software used for statistical analyses was STATA v.15 (Stata Corp., College Station, TX, USA) and R 1.3.1073.

\section{Results}

\subsection{Patients}

By January 2021, a total of 5000 patients had been admitted to the $\mathrm{TCH}$, of which 4884 had been discharged. Of these, 4670 patients who agreed to participate in the follow-up survey and met the inclusion criteria were followed up by telephone. In total, 21,553 follow-up calls were performed between September 2020 and January 2021. The number of responders declined progressively with 3914 responses on day 1, 1303 responses on day 30, and 928 responses on day 90. 
The main demographic characteristics of patients are shown in Table 1. Patients had a median (IQR) age of 48 (37-58) years, 50.5\% were female, 21.2 had type 2 diabetes, $23.1 \%$ had hypertension, $38.7 \%$ were overweight, and $37.5 \%$ were obese.

Over $75 \%$ of patients met the criteria for the green NEWS score category at admission (Table 2). During hospitalisation, $15.2 \%$ required HFNC, and only $4.6 \%$ of patients were admitted to the ICU. The median (IQR) hospitalisation stay was $8(6-12)$ days, and $99.4 \%$ of patients were discharged from the hospital. While over $80 \%$ of patients maintained normal haemoglobin levels during hospitalisation, $13.2 \%$ had increased D-dimer levels (>1500 ng/mL), 31.2\% had increased levels $(336.2 \mathrm{ug} / \mathrm{L})$ of ferritin, $30.7 \%$ had high levels $(>233 \mathrm{U} / \mathrm{L}$ ) of lactic dehydrogenase, and $31.6 \%$ had a low absolute lymphocyte count $\left(<1000 \times 10^{3}\right.$ cells/ $\left.\mu \mathrm{L}\right)$ (Table 2$)$.

Data on pulse oximetry from patients who did not require oxygen at discharge were available for the first 21 days. Of note, the median oxygen saturation was $94 \%$, and the mean saturation remained similar throughout the 21 days (93.6\% on day 1 to $94.1 \%$ on day 21 ). Saturation remained below $90 \%$ in $2.6 \%$ (56) of patients. Temperature measurements yielded a median temperature of $36.2^{\circ} \mathrm{C}$, and the mean temperature remained mostly unchanged for 21 days.

\subsection{Symptoms}

We identified 45 symptoms attributed to COVID-19 and classified them into eight body system clusters (neurological; mood disorders; systemic; respiratory; musculoskeletal; ear, nose, and throat; dermatological; and gastrointestinal) (Supplementary Figure 1).

The change in symptoms over time is shown in Figure 1a. The symptoms with a significant decrease in frequency from day 30 to day 90 were fatigue (difference in frequencies: $-9.5 \%$, $p<0.0001)$, cough $(-7.1 \%, p<0.0001)$, chest pain $(-4.9 \% p<0.0001)$, tremors $(-3.8 \% ; p<0.0001)$, muscle pain $(-3.2 \% ; p=0.01)$, sore throat $(-3.6 \% ; p=0.03)$, dizziness $(-2.8 \% ; p=0.04)$, and diminished exercise capacity $(-2.5 \% ; \mathrm{p}=0.04)$. Most symptoms tended to decrease in frequency between day 30 and day 90 , except for alopecia (difference in frequencies: $+12.6 \%, p<0.00001)$, rhinorrhoea $(+1.8 \%$, $\mathrm{p}=0.25)$, lacrimation $(+1.2 \%, \mathrm{p}=0.71)$, lack of concentration $(+0.79 \%, p=0.41)$, paraesthesia $(+0.78 \%$, $\mathrm{p}=0.56)$, arthralgia $(+0.61 \%, p=0.54)$, and memory loss $(+0.49 \%, p=0.53)$, all of which showed increases in frequency over that period. Headache and insomnia were the most common neurological complaints, while sadness, desire to cry, anguish, anger, and anhedonia were the most common complaints in the mood disorder cluster (Figure 1b and 1c). Fatigue, cough, back pain, throat pain, hair loss, nausea, and diarrhoea were the other major complaints in the remaining clusters.

Significant differences in the frequency of all symptom clusters were observed between 90and 30-days post-discharge (Figure 2). At 90 days post-discharge, there were slight decreases in the 
frequency of symptoms across all clusters, except for the dermatological symptom cluster, in which the frequency of symptoms had significantly increased from $22.4 \%$ to $33.5 \%(p<0.0001)$. However, persistent symptoms were still markedly high in the neurological, mood disorder, systemic, musculoskeletal, and ear, nose, and throat symptom clusters. At 30 days post-discharge, the proportions of patients with and without symptoms were $76.2 \%$ and $23.8 \%$, respectively, while at 90 days the proportions of patients with and without symptoms were $68.0 \%$ and $32.0 \%$, respectively. Furthermore, over $16 \%$ and $22 \%$ of patients still had at least one symptom after 30 and 90 days, respectively.

When comparing symptom persistence in patients who had or had not undergone IMV, the use of IMV increased the frequency of symptoms by over $13 \%$ at 30 days post-discharge $(75.5 \%$ [936/1239] and 88.7\% [55/62]); however, this was non-significant ( $p=0.31)$. The difference in the proportion of patients with persistent symptoms at 90 days among those who underwent IMV and those who did not was also non-significant (69.2\% [612/884] and 68.9\% [31/45], $p=0.27)$. By symptom cluster, the majority of complaints of patients who underwent IMV at 30 days were in the neurological, systemic, mood disorder, and respiratory clusters (Figure 3). Although neurological symptoms remained the most frequent at 90 days, there was a shift to dermatological symptoms as the second most frequent symptom cluster. Further, at 90 days, the trend in frequency across symptom clusters resembled that of patients who did not undergo IMV.

We also compared the frequency of symptoms by sex (Figure 4). Of note, in both women and men, the frequencies of symptoms such as alopecia, joint pain, paraesthesia, lack of concentration, rhinorrhoea, and memory loss were higher at 90 days than at 30 days post-discharge. Women seemed to be more affected than men for most of these symptoms, particularly alopecia. At 90 days, the frequency of dermatological symptoms in women was $45.9 \%$, compared with $21.2 \%$ in men.

\subsection{Multiple logistic regression models}

Table 3 and Supplementary Figure 2a-d show the multiple logistic regression analyses for relevant background factors and symptom clusters. At 30 and 90 days, significant associations were observed with the female sex compared with the male sex, with a higher risk shown for neurological (OR: 0.59 [95\% $\mathrm{Cl} 0.43-0.81$ ], $\mathrm{p}<0.01$ and 0.38 [95\% $\mathrm{Cl} 0.24-0.62$ ], $\mathrm{p}<0.001$ ), mood disorder (OR: 0.57 [95\% $\mathrm{Cl} 0.41-0.78$ ], $\mathrm{p}<0.001$ and 0.42 [95\% $\mathrm{Cl} 0.25-0.70$ ], $\mathrm{p}<0.001$ ), musculoskeletal (OR: 0.59 [95\% Cl $0.42-0.82$ ], $\mathrm{p}<0.01$ and 0.50 [95\% $\mathrm{Cl} 0.30-0.84], \mathrm{p}<0.01)$ and dermatological $(0.27$ [95\% $\mathrm{Cl}$ $0.18-0.41$ ],$p<0.001$ and 0.27 [95\% $\mathrm{Cl} 0.16-0.45], p<0.001$ ) symptoms. Compared with the male sex, female sex was also associated with a higher risk of presenting respiratory symptoms at 30 days and systemic symptoms at 90 days. 
Compared with normal weight, obesity was significantly associated with respiratory symptoms, and HFNC use versus no use during hospitalisation was associated with musculoskeletal and dermatological symptom clusters at 30 days post-discharge. Dexamethasone treatment versus no dexamethasone use was significantly associated with respiratory, musculoskeletal, and dermatological symptom clusters at 30 days post-discharge. Compared with normal levels, elevated D-dimer levels were associated with ear, nose, and throat symptoms at 30 days post-discharge and with respiratory, musculoskeletal, and dermatological symptom clusters at 90 days post-discharge. Significant associations were noted between one-day increases in hospital stay duration and neurological (30 days post-discharge) and respiratory symptom clusters (30- and 90-days postdischarge).

\section{Discussion}

This longitudinal, prospective, observational, single-centre study analysed the most frequent symptoms that persisted in patients with COVID-19 at 30- and 90-days post-discharge from the TCH in Mexico City. Notably, $76.2 \%$ had at least one of the 45 identified COVID-19 symptoms at 30 days post-discharge, with $68.0 \%$ of patients having at least one of these symptoms persist to 90 days postdischarge. When grouped in clusters by body systems, we identified eight symptom clusters. Among these, the most relevant symptom clusters that persisted in $>30 \%$ of patients at 90 days postdischarge were the neurological, dermatological, and mood disorder symptom clusters. The changes in symptom cluster frequency over time indicate that COVID-19 is not only a viral disease with an acute phase, but that it can develop into a chronic condition with long-term consequences that are frequent and disabling. Some moderate associations were also observed between long COVID symptom clusters and obesity, dexamethasone use, increased D-dimer levels, and hospital stay duration. Although the early symptoms of COVID-19 have been amply characterised, further evidence of long or chronic COVID-19 is needed to offer these patients the appropriate clinical management, rehabilitation, and support via public health strategies after the acute phase of the disease.

The present proportions of patients reporting long-term symptoms are similar to those reported in a cohort of patients discharged from a temporary hospital in Wuhan. ${ }^{10}$ In that cohort, $76 \%$ of patients discharged from that hospital had at least one symptom at the 6-month follow-up. In contrast, we report a higher incidence than what was reported in a single-centre study in Wuhan at 3 months after discharge, in which $49.6 \%$ had at least one general symptom after discharge. ${ }^{15}$

Previous coronavirus epidemics, namely SARS and MERS, have also resulted in long-term sequelae ${ }^{16}$ including fatigue, shortness of breath, myalgia, depression, alopecia, insomnia, and mental disorders such as anxiety and post-traumatic stress disorder that lasted from 3 months to over 1 year after the acute illness. During the current pandemic, concerns were raised early on that this 
could happen with COVID-19. ${ }^{17}$ Recently, a large retrospective database study followed 236379 patients for 6 months after a COVID-19 diagnosis and compared symptoms against patients who had influenza or a respiratory tract infection during the same period. ${ }^{18}$ They reported that the presence of COVID-19 was significantly associated with neurological and psychiatric symptoms with an estimated incidence of 33.62\% at 6 months. The neurological and psychiatric consequences of COVID-19 that were identified in that study included ischaemic stroke, intracranial haemorrhage, psychotic disorders, anxiety and mood disorders, insomnia, and substance use disorders. These symptoms, which we also identified in our study, are usually chronic or recurring conditions that may persist beyond 3 and 6 months, and as such add further support to the notion of the chronicity of COVID-19.

The ten most frequent individual symptoms at 30 - and 90 days post-discharge were fatigue, headache, sadness, alopecia, insomnia, desire to cry, anguish, anger, anhedonia, and back pain, which are similar to those described in previous reports. ${ }^{5,11,15,19}$ Most recently, a study on the attributes and predictors of long COVID-19 also reported similar individual symptoms (i.e., fatigue, headache, dyspnoea, and anosmia) that persisted for 12 weeks. ${ }^{3}$ Although symptoms like fatigue, cough, and chest pain decreased over time in our study, patients who were discharged from the TCH reported higher frequencies of alopecia, rhinorrhoea, lacrimation, lack of concentration, paraesthesia, arthralgia, and memory loss at 90 days compared with 30 days.

Of note, Xiong et al. discuss in their paper that alopecia may be a distinctive long-term feature of COVID-19 survivors and that it almost exclusively affected women. ${ }^{15}$ We also found that alopecia increased over time, that it mainly affected women, and at 90 days, the proportion of women who suffered alopecia was double that of men. Possible reasons for alopecia in women include inflammation and immunity ${ }^{20,21}$ and a possible association with emotional distress, ${ }^{22}$ which seems plausible given the high proportion of patients in our population who reported sadness and anxiety. These findings indicate that healthcare systems must develop strategies to provide mental health support to COVID-19 survivors with persistent symptoms. ${ }^{23}$

In the present study, women reported having persistent COVID-19 symptoms more often than men, which is consistent with the reports of two previous single-centre cohort studies at COVID-19 hospitals in Wuhan, ${ }^{10}$ and a 12-week follow-up study in the UK. ${ }^{3}$ Further, the association between female sex and long COVID-19 symptoms was clearly observed across several symptom clusters, including the neurological, mood disorder, musculoskeletal, and dermatological clusters. Of the biomarkers evaluated, increased D-dimer levels (>1000 or $1500 \mathrm{U} / \mathrm{L}$ ) were significantly associated with ear, nose, and throat, respiratory, musculoskeletal, and dermatological symptom clusters.

In contrast with the cohort study by Huang et al. in China, ${ }^{10}$ where the presence of persisting symptoms was linked with the severity of the initial COVID-19 illness, we found that patients tended to present long-term health consequences of COVID-19 regardless of their initial disease severity. 
However, we cannot rule out selection bias as the TCH admitted many patients with mild or moderate disease. When we compared symptom persistence between patients who had undergone IMV versus those who did not, IMV increased the frequency of long COVID-19 symptoms by $13 \%$ at 30 days postdischarge. Interestingly, at 90-days post-discharge, the frequency of symptoms was similar to those of patients who did not receive IMV. Our findings are also broadly aligned with a recent study focusing on persistent neurological symptoms at 6-months. The incidences and risk of presenting such persistent symptoms were greater, but not limited to patients who were hospitalized. Of note, in that study, these outcomes were even more marked among patients who had required intensive care or had developed encephalopathy during their hospital stay. ${ }^{18}$

Some studies have suggested that post-COVID-19 symptoms resemble fibromyalgia, post-viral fatigue syndrome, or chronic fatigue viral syndrome. ${ }^{24-26}$ However, these associations are speculative, and further research is needed to clarify the underlying pathophysiology of long COVID-19 and whether applying similar clinical management strategies would be beneficial.

This study's main limitation was that many patients were lost to follow-up by the end of the observation period. Additionally, the results depended on a self-reported questionnaire. Patient responses may have been subject to recall bias, which could have affected the accuracy of the information obtained by the telephone follow-up. Further, patients did not undergo a physical examination or in-person interview during follow-up to validate their responses. However, the electronic medical records at the $\mathrm{TCH}$ were considered a reliable source of data.

In conclusion, a large proportion of patients who experienced COVID-19 and who were discharged from the hospital presented long-term health consequences of COVID-19 at 30- and 90days post-discharge. Our observations suggest that COVID-19 is a chronic illness that affects several organs and systems, and that the presence of these persisting symptoms is not limited by the severity of the initial COVID-19 disease. We propose that the management and rehabilitation of COVID-19 patients should include strategies that include neurological, mood disorder, and dermatological symptoms.

As a consensus has yet to be reached regarding the terminology, definition, pathophysiology, characteristics, evolution, and treatment for this post-viral syndrome, the present findings are intended to expand on the presently available data and aid the development of appropriate and multidisciplinary strategies to manage symptoms and promote physical, mental, and emotional recovery. However, longer-term studies are needed to clarify any association among COVID-19 symptoms, prolonged hospital stay, disease severity, and hospitalization stressors. 
Author contributions: Conceptualization, R.M.W-C., E.X.R.C., C.A.R.V., J.L.G., L.M.J., M.L.R.C., A.R.V.R., M.A.A., D-A.A-H., H.G-R., G.F.D., R.T-C. and R.R.V.V.; data curation, L.M.J, M.L.R.C., A.R.V.R., L.R.G.C. and A.J.F.; formal analysis, R.M.W-C., E.X.R.C., C.A.R.V., J.L.G., L.M.J., M.L.R.C., A.R.V.R., L.R.G.C., A.J.F., L.A.M.J., D-A.A-H., H.G-R., G.F.D., R.T-C. and R.R.V.V.; funding acquisition, H.G-R., R.T-C. and R.R.V.V.; investigation, R.M.W-C., E.X.R.C., C.A.R.V., J.L.G., L.M.J., M.L.R.C., A.R.V.R., S.A.F., M.S.F., J.A.H.C., N.A.M., L.F.C., L.A.M.J., D-A.A-H., H.G-R., G.F.D., R.T-C. and R.R.V.V.; methodology, R.M.W-C., E.X.R.C., C.A.R.V., J.L.G., L.M.J., M.L.R.C., A.R.V.R., L.A.M.J., D-A.A-H., H.G-R., G.F.D., R.T-C. and R.R.V.V.; project administration, R.M.W-C., E.X.R.C., C.A.R.V., J.L.G., S.A.F., H.H.B., L.M.C., M.A.A., J.A.H.C., N.A.M., L.F.C., H.G-R. and R.R.V.V.; resources, all authors; software, J.L.G., L.M.J., M.L.R.C., L.R.G.C., A.J.F. and L.A.M.J.; supervision, R.M.W-C., E.X.R.C., C.A.R.V., J.L.G., L.M.J., M.L.R.C., S.A.F., J.A.H.C., H.G-R., R.T-C. and R.R.V.V.; validation, all authors; visualization, R.M.W-C., E.X.R.C., C.A.R.V., J.L.G., L.M.J., M.L.R.C., A.R.V.R., S.A.F., M.S.F., H.H.B., L.M.C., M.A.A., J.A.H.C., N.A.M., L.F.C., L.R.G.C., A.J.F., L.A.M.J., D-A.A-H., H.G-R., R.T-C. and R.R.V.V.; writing-original draft preparation, all authors; writing-review and editing, all authors.

Funding: This research was funded by Carlos Slim Foundation

Institutional Review Board Statement: The study was conducted according to the guidelines of the Declaration of Helsinki and approved by The Research Ethics Committee of the Faculty of Medicine of the National Autonomous University of Mexico (FM/DI/094/2020).

Data Availability Statement: All data collected for this study will be made available upon reasonable request to the corresponding author.

Acknowledgments: The authors wish to thank Keyra Martinez Dunn, MD and James Graham, PhD of Edanz Pharma, for providing medical writing support.

Conflict of Interests: R.R.V.V., E.X.R.C., C.A.R.V., J.L.G., L.M.J., A.R.V.R., S.A.F., M.S.F., H.H.B., L.M.C., M.A.A., J.A.H.C., N.A.M., L.F.C., L.R.G.C. and A.J.F. are employees of the Temporary COVID-19 Hospital. L.A.M.J., D-A.A-H., H.G-R. and R.T-C. are employees of The Carlos Slim Foundation, which funded this research. The authors declare no other conflicts of interest. The study sponsor was involved in the analysis and interpretation of data and writing of the report. All authors confirm that they had full access to all the study data and accept responsibility to submit for publication. 


\section{References}

1. WHO Coronavirus Disease (COVID-19) Dashboard. Available online: https://covid19.who.int/ (accessed on 20 May 2021).

2. Han, E.; Tan, M.M.J.; Turk, E.; et al. Lessons learnt from easing COVID-19 restrictions: an analysis of countries and regions in Asia Pacific and Europe. Lancet 2020, 396, 1525-1534.

3. Sudre, C.H.; Murray, B.; Varsavsky, T.; et al. Attributes and predictors of long COVID. Nat Med 2021, 27, 626-631.

4. Arnold, D.T.; Hamilton, F.W.; Milne, A.; et al. Patient outcomes after hospitalisation with COVID19 and implications for follow-up: results from a prospective UK cohort. Thorax 2020, 76, 399401.

5. Carfi, A.; Bernabei, R.; Landi, F. Persistent symptoms in patients after acute COVID-19. JAMA 2020, 324, 603-605.

6. Carvalho-Schneider, C.; Laurent, E.; Lemaignen A.; et al. Follow-up of adults with noncritical COVID-19 two months after symptom onset. Clin Microbiol Infect 2021, 27, 258-263.

7. McMahon, D.E.; Gallman, A.E.; Hruza, G.J.; et al. Long COVID in the skin: a registry analysis of COVID-19 dermatological duration. Lancet Infect Dis 2021, 21, 313-314.

8. Ellul, M.A.; Benjamin, L.; Singh, B.; et al. Neurological associations of COVID-19. Lancet Neurol 2020, 19, 767-783.

9. Paterson, R.W.; Brown, R.L.; Benjamin, L.; et al. The emerging spectrum of COVID-19 neurology: clinical, radiological and laboratory findings. Brain 2020, 143, 3104-3120.

10. Huang, C.; Huang, L.; Wang, Y.; et al. 6-month consequences of COVID-19 in patients discharged from hospital: a cohort study. Lancet 2021, 397, 220-232.

11. Davis, H.E.; Assaf, G.S.; McCorkell, L.; et al. Characterizing long COVID in an international cohort: 7 months of symptoms and their impact. medRxiv 2021.

12. NICE Guidelines on long COVID. Available online: https://www.nice.org.uk/guidance/ng188 (accessed on 3 March 2021).

13. Norton, A.; Olliaro, P.; Sigfrid, L.; et al. Long COVID: tackling a multifaceted condition requires a multidisciplinary approach. Lancet Infect Dis 2021, 21, 601-602.

14. Martinez-Juarez, L.A.; Sedas, A.C.; Orcutt, M.; Bhopal, R. Governments and international institutions should urgently attend to the unjust disparities that COVID-19 is exposing and causing. EClinicalMedicine 2020, 23, 100376

15. Xiong, Q.; Xu, M.; Li, J.; et al. Clinical sequelae of COVID-19 survivors in Wuhan, China: a single-centre longitudinal study. Clin Microbiol Infect 2021, 27, 89-95.

16. O'Sullivan, O. Long-term sequelae following previous coronavirus epidemics. Clin Med (Lond) 2021, 21, e68-e70.

17. Rogers, J.P.; David, A.S. A longer look at COVID-19 and neuropsychiatric outcomes. Lancet Psychiatry 2021, 8, 351-352.

18. Taquet, M.; Geddes, J.R.; Husain, M.; Luciano, S.; Harrison, P.J. 6-month neurological and psychiatric outcomes in 236379 survivors of COVID-19: a retrospective cohort study using electronic health records. Lancet Psychiatry 2021.

19. Lopez-Leon, S.; Wegman-Ostrosky, T.; Perelman, C.; et al. More than 50 Long-term effects of COVID-19: a systematic review and meta-analysis. medRxiv 2021.

20. Magro, C.M.; Rossi, A.; Poe, J.; Manhas-Bhutani, S.; Sadick, N. The role of inflammation and immunity in the pathogenesis of androgenetic alopecia. J Drugs Dermatol 2011, 10, 14041411.

21. Peyravian, N.; Deo, S.; Daunert, S.; Jimenez, J.J. The inflammatory aspect of male and female pattern hair loss. J Inflamm Res 2020, 13, 879-881.

22. Mieczkowska, K.; Deutsch, A.; Borok, J.; et al. Telogen effluvium: a sequela of COVID-19. Int J Dermatol 2021, 60, 122-124.

23. Pallanti, S.; Grassi, E.; Makris, N.; Gasic, G.P.; Hollander, E. Neurocovid-19: A clinical neuroscience-based approach to reduce SARS-CoV-2 related mental health sequelae. $J$ Psychiatr Res 2020, 130, 215-217. 
24. Perrin, R.; Riste, L.; Hann, M.; Walther, A.; Mukherjee, A.; Heald, A. Into the looking glass: Postviral syndrome post COVID-19. Med Hypotheses 2020, 144, 110055.

25. Wood, E.; Hall, K.H.; Tate, W. Role of mitochondria, oxidative stress and the response to antioxidants in myalgic encephalomyelitis/chronic fatigue syndrome: A possible approach to SARS-CoV-2 'long-haulers'? Chronic Dis Transl Med 2021, 7, 14-26.

26. Wostyn, P. COVID-19 and chronic fatigue syndrome: Is the worst yet to come? Med Hypotheses 2021, 146, 110469. 


\section{Figure legends}

Figure 1. Frequently reported symptoms and symptom changes over time (a) frequency of symptoms by cluster after 30 days post-discharge (b), and frequency of symptoms by cluster after 90 days postdischarge (c)

${ }^{*}$ Comparison between 30 and 90 days with Chi square or Fisher exact test

Figure 2. Persistence of symptoms by symptom cluster over time

Figure 3. Persistence of symptom clusters stratified by patients who underwent IMV versus no IMV at 30- and 90-days post-discharge

IMV, invasive mechanical ventilation

Figure 4. Persistence of symptom clusters stratified by sex at 30 - and 90-days post-discharge 
Figures

Figure 1a

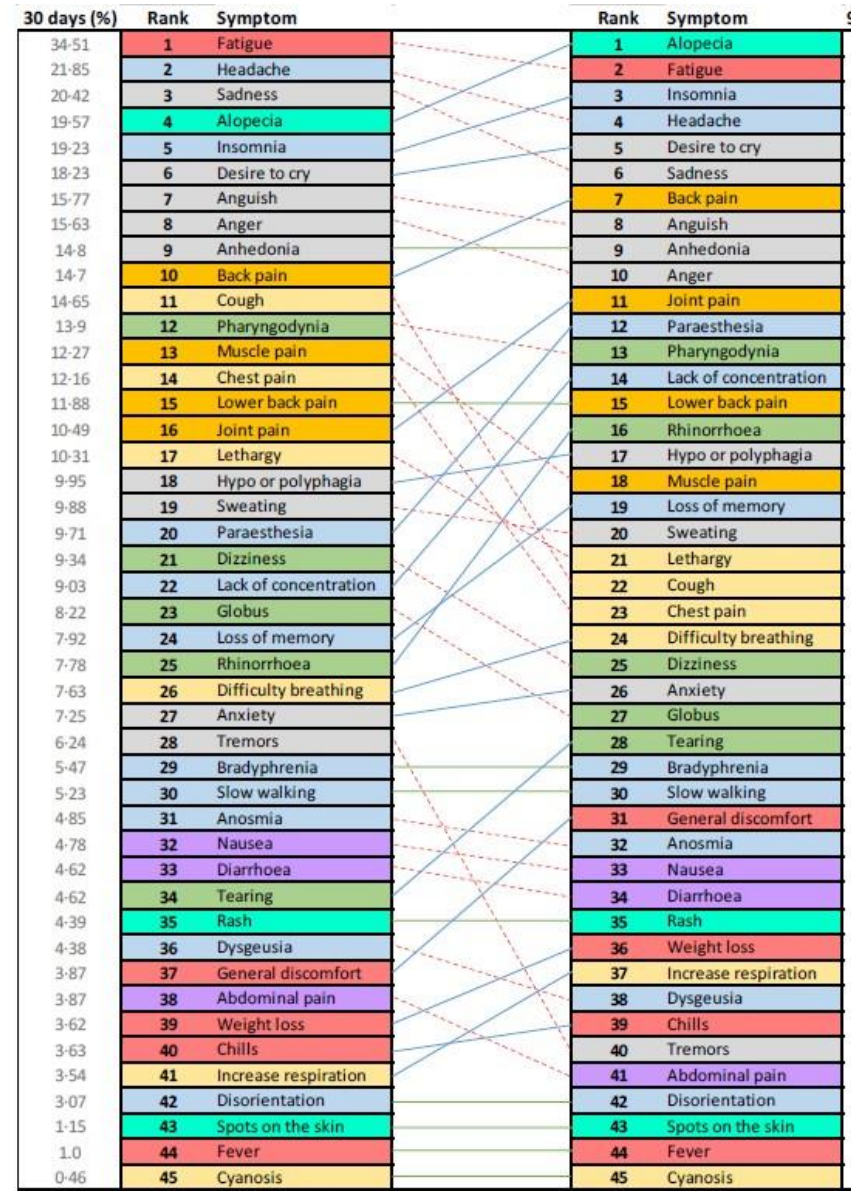

\begin{tabular}{|c|c|c|c|}
\hline 0 days (\%) & Symptom & $\%$ Change & p value ${ }^{*}$ \\
\hline $32 \cdot 21$ & Fatigue & -9.5 & $<0.0001$ \\
\hline 24.97 & Headache & -4.8 & $<0-01$ \\
\hline 17.58 & Sadness & $-4 \cdot 4$ & $<0.01$ \\
\hline 17.04 & Alopecia & $12 \cdot 6$ & $<0-00001$ \\
\hline 16.49 & Insomnia & $-1 \cdot 7$ & 0.32 \\
\hline $16 \cdot 04$ & Desire to cry & $-1 \cdot 7$ & 0.25 \\
\hline 13.36 & \begin{tabular}{|l} 
Anguish \\
\end{tabular} & $-3 \cdot 1$ & 0.05 \\
\hline $12 \cdot 72$ & Anger & $-3 \cdot 3$ & 0.02 \\
\hline 12.63 & Anhedonia & $.2 \cdot 2$ & $0-1$ \\
\hline $12 \cdot 3$ & Back pain & -1.3 & 0.34 \\
\hline 11.1 & \begin{tabular}{|l} 
Cough \\
\end{tabular} & $-7 \cdot 1$ & $<0.0001$ \\
\hline 10.49 & Pharyngodynia & -3.6 & 0.03 \\
\hline 10.34 & \begin{tabular}{|l} 
Muscle pain \\
\end{tabular} & $-3 \cdot 2$ & 0.01 \\
\hline 982 & Chest pain & -4.9 & $<0,0001$ \\
\hline 971 & Lower back pain & $-2 \cdot 2$ & 0.12 \\
\hline 9.6 & \begin{tabular}{|l|l} 
Joint pain \\
\end{tabular} & 0.6 & 0.54 \\
\hline 949 & Lethargy & -2.5 & 0.04 \\
\hline 9.04 & Hypo or polyphagia & -0.5 & 0.52 \\
\hline 8.41 & Sweating & -1.9 & 0.14 \\
\hline 7.99 & Paraesthesia & 0.8 & 0.56 \\
\hline 7.77 & \begin{tabular}{|l} 
Dizziness \\
\end{tabular} & $.2 \cdot 8$ & 0.04 \\
\hline 7.58 & Lack of concentration & 0.8 & 0.41 \\
\hline 7.22 & Gobus & $-2 \cdot 3$ & 0.13 \\
\hline 6.69 & Loss of memory & 0.5 & 0.53 \\
\hline 6.51 & Rhinorrhoea & 1.8 & 0.25 \\
\hline $6-14$ & Difficulty breathing & -0.9 & 0.33 \\
\hline 5.93 & \begin{tabular}{|l|} 
Anxiety \\
\end{tabular} & -1.1 & 0.13 \\
\hline 5.83 & Tremors & -3.8 & $<0.0001$ \\
\hline $4 \cdot 97$ & Bradyphrenia & -0.5 & $0-5$ \\
\hline 4.0 & Slow walking & $-1 \cdot 2$ & 0.26 \\
\hline 3.67 & Anosmia & -1.5 & 0.11 \\
\hline 3.35 & \begin{tabular}{|l|} 
Nausea \\
\end{tabular} & .1 .5 & 0.14 \\
\hline 3.24 & Diarrhoea & -1.4 & 0.36 \\
\hline 3.24 & Tearing & $1 \cdot 2$ & 0.71 \\
\hline 3.02 & Rash & $-1 \cdot 4$ & 0.08 \\
\hline 2.91 & Dysgeusia & -1.7 & 0.07 \\
\hline 2.81 & General discomfort & .0 .2 & 0.39 \\
\hline 2.7 & Abdominal pain & -1.6 & 0.04 \\
\hline 2.59 & \begin{tabular}{|l} 
Weight loss \\
\end{tabular} & -0.7 & $0-6$ \\
\hline $2-48$ & \begin{tabular}{|l} 
Chills \\
\end{tabular} & -1.0 & 0.06 \\
\hline $2 \cdot 26$ & Increase respiration & -0.7 & 0.65 \\
\hline 2.05 & \begin{tabular}{|l|} 
Disorientation \\
\end{tabular} & -1.0 & 0.16 \\
\hline 0.97 & Spots on the skin & -0.2 & 0.74 \\
\hline 0.97 & Fever & 0.0 & 0.42 \\
\hline 0.43 & Cyanosis & 0.0 & 0.47 \\
\hline
\end{tabular}


Figure $1 \mathrm{~b}$

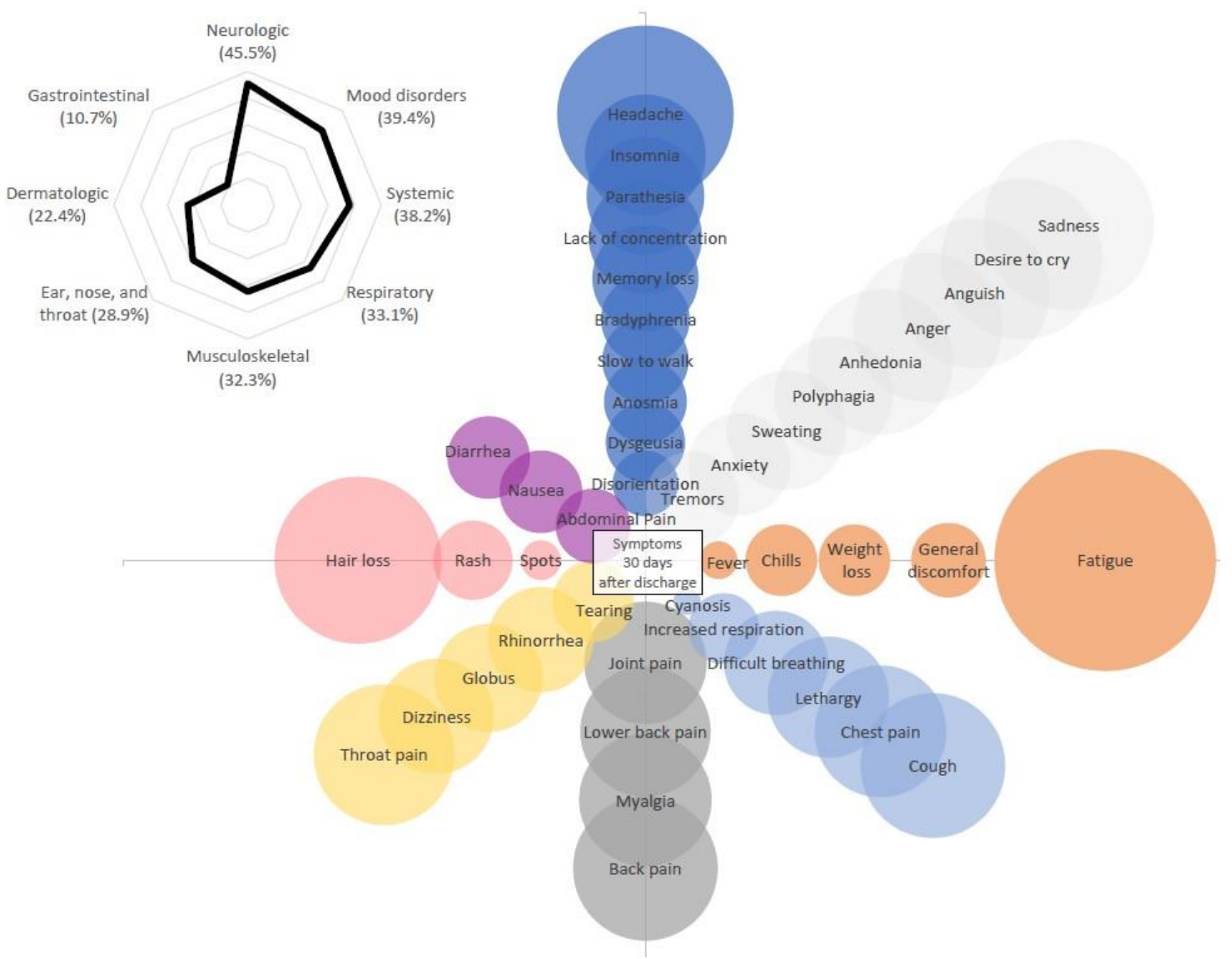


Figure $1 \mathrm{c}$

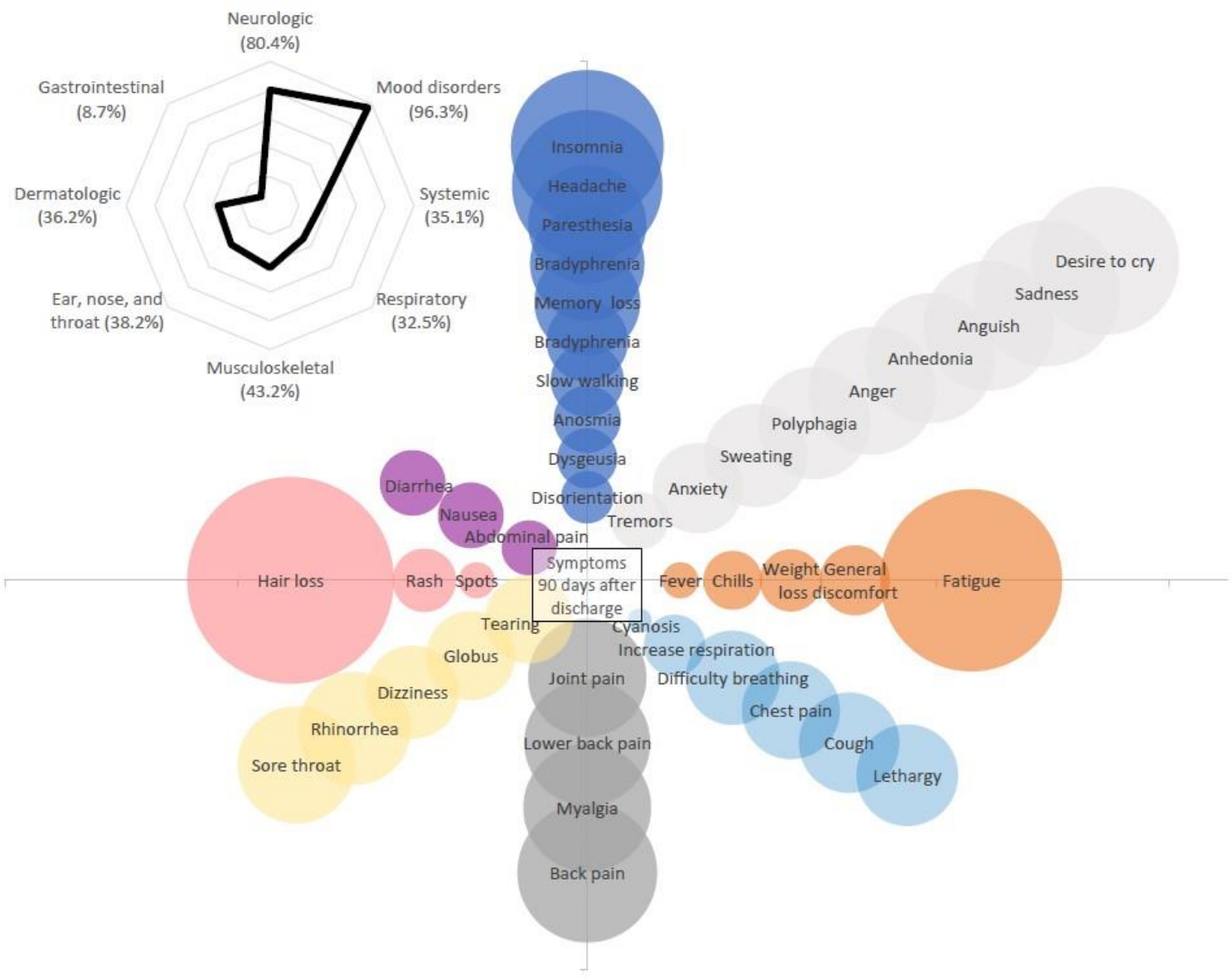

Figure 2

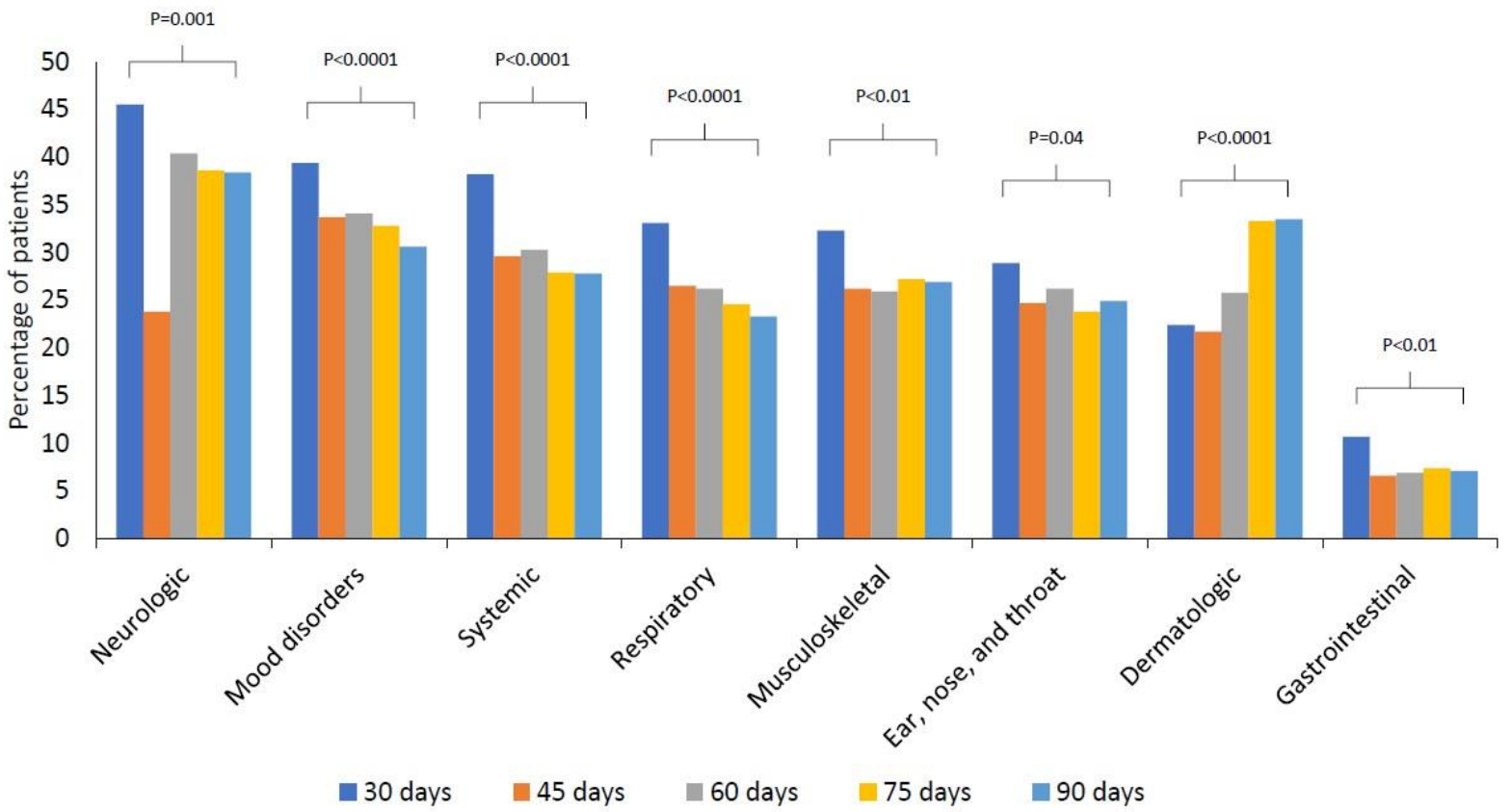


Figure 3

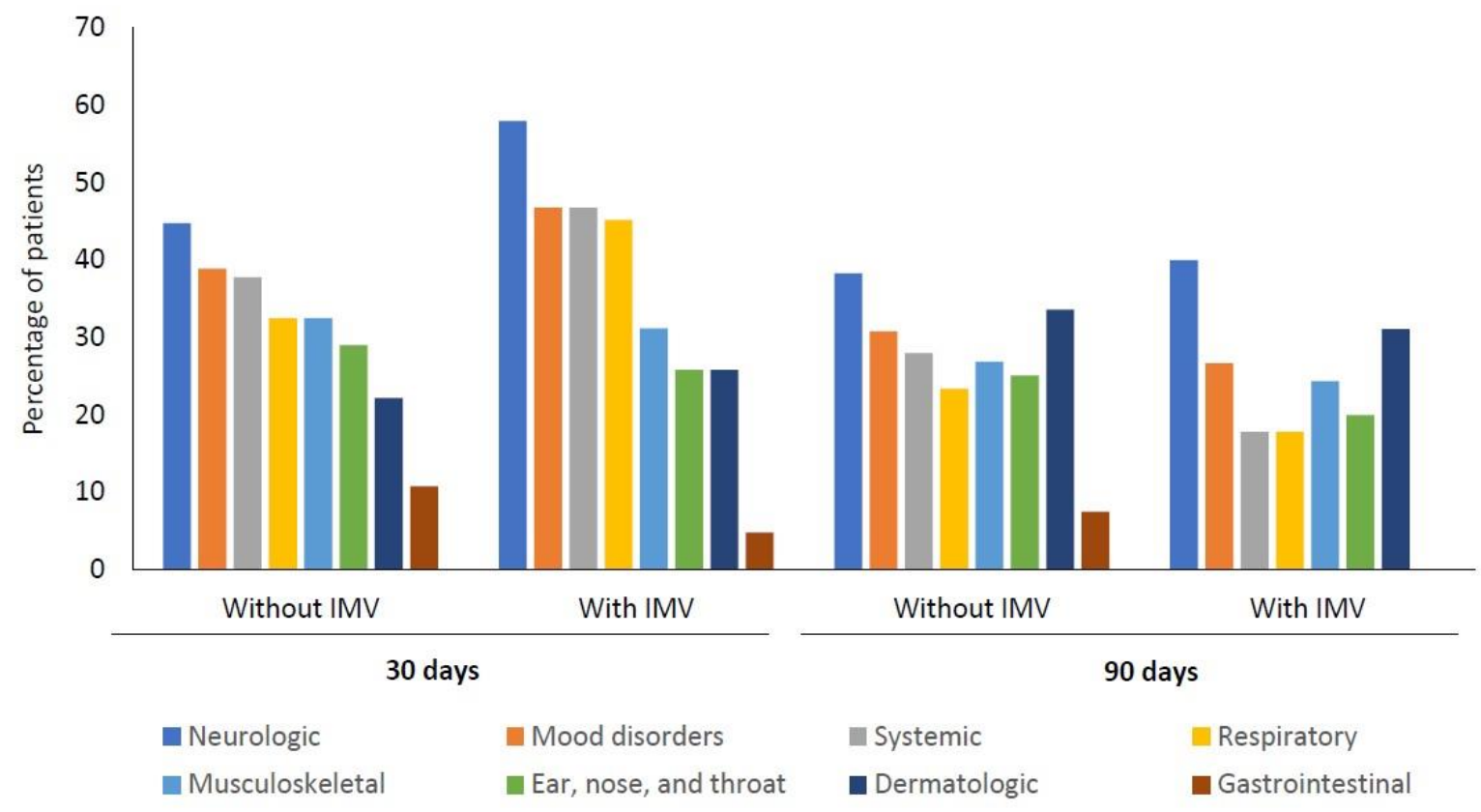

Figure 4

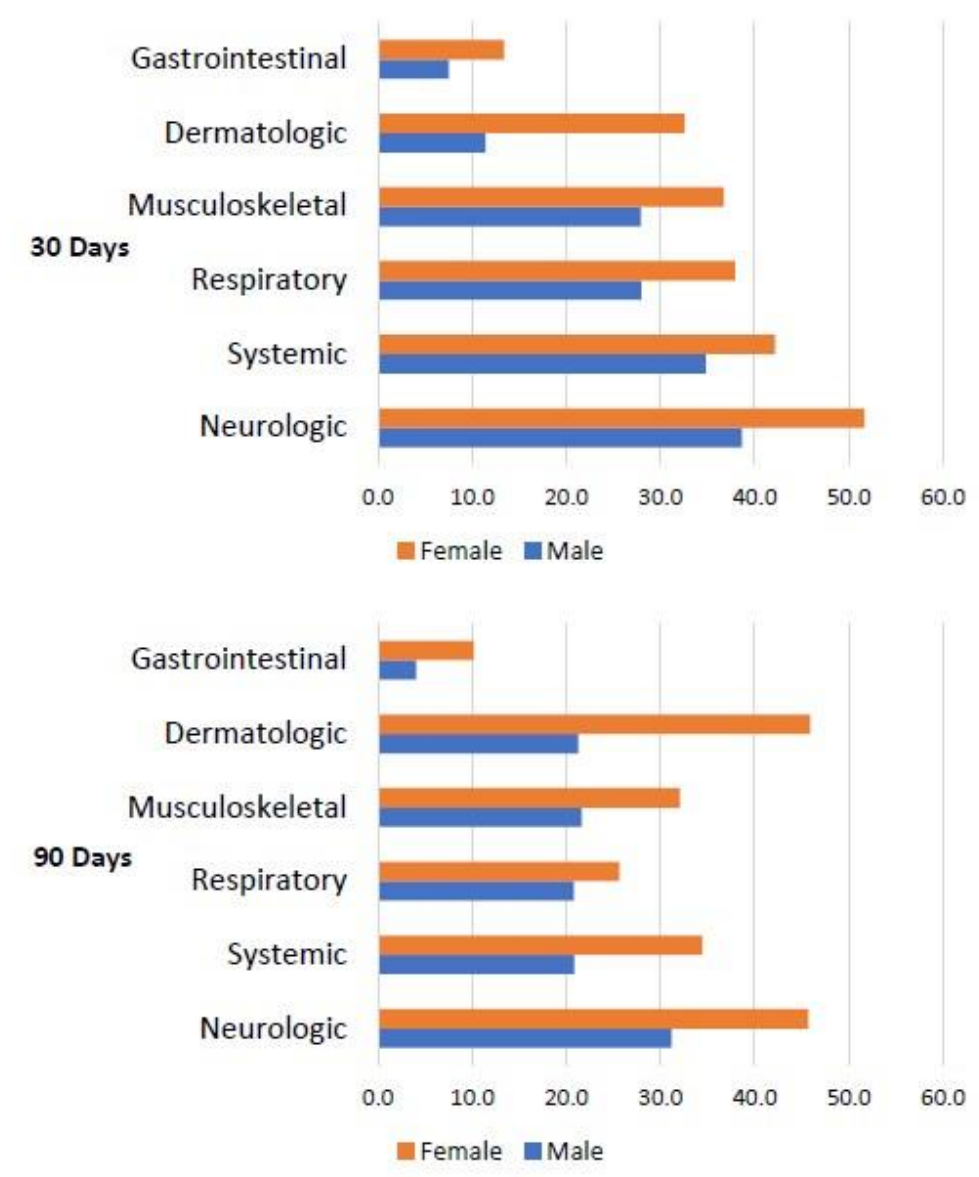




\section{Tables}

Table 1. Characteristics of patients enrolled in this study

Total $(\mathrm{N}=4670)$

\begin{tabular}{|c|c|}
\hline Characteristics at admission & \\
\hline Age (years) & \\
\hline Median (IQR) & $48(37-58)$ \\
\hline Sex & \\
\hline Females, n (\%) & $2358(50.5)$ \\
\hline Males, n (\%) & $2312(49.5)$ \\
\hline Education level, n (\%) & \\
\hline Primary school or less & $640(13.7)$ \\
\hline Middle school (or incomplete) & $893(19.1)$ \\
\hline High School or incomplete/University incomplete & $1648(35.3)$ \\
\hline University and/or postgraduate & $1157(24.8)$ \\
\hline No registry & $332(7.1)$ \\
\hline Health services coverage, $n(\%)$ & \\
\hline Insurance & $2019(43.2)$ \\
\hline Government & $130(2.8)$ \\
\hline None & $1749(37.5)$ \\
\hline No registry & $772(16.5)$ \\
\hline Smoking & \\
\hline Yes, n (\%) & $1362(29.2)$ \\
\hline Alcohol consumption & \\
\hline Yes, n (\%) & $1707(36.6)$ \\
\hline Diabetes & \\
\hline $\mathrm{n}(\%)$ & $988(21.2)$ \\
\hline Uncontrolled diabetes mellitus (glucose $>180 \mathrm{mg} / \mathrm{dL}$ ) & $537(11.5)$ \\
\hline Hypertension & \\
\hline $\mathrm{n}(\%)$ & $1079(23.1)$ \\
\hline Uncontrolled hypertension (Blood pressure $>140 / 100 \mathrm{mmHg}$ ) & $210(4.5)$ \\
\hline BMI $\left(\mathbf{k g} / \mathrm{m}^{2}\right)$ & \\
\hline Normal, n (\%) & $777(16.6)$ \\
\hline Overweight, $\mathrm{n}(\%)$ & $1807(38.7)$ \\
\hline Obesity, n (\%) & $1750(37.5)$ \\
\hline No registry & $336(7.2)$ \\
\hline Charlson index categories, $\mathrm{n}(\%)$ & \\
\hline Absence & $2880(61.7)$ \\
\hline Low comorbidity & $1566(33.5)$ \\
\hline High Comorbidity & $224(4.8)$ \\
\hline
\end{tabular}

BMI, body mass index; IQR, interquartile range 
Table 2. Frequency of symptoms and main clinical conditions at admission

\begin{tabular}{|c|c|}
\hline & Total $(\mathrm{N}=4670)$ \\
\hline \multicolumn{2}{|l|}{ Frequency of symptoms at admission, $\mathbf{n}(\%)$} \\
\hline Headache & $2721(58.3)$ \\
\hline Cough & $2648(56.7)$ \\
\hline Myalgias & $2489(53.3)$ \\
\hline Fever & $2236(47.9)$ \\
\hline Arthralgia & $2009(43.0)$ \\
\hline Pharyngodynia & $1659(35.5)$ \\
\hline Anosmia & $1056(22.6)$ \\
\hline Dysgeusia & $1015(21.7)$ \\
\hline Rhinorrhoea & $1002(21.5)$ \\
\hline Diarrhoea & $655(14.0)$ \\
\hline Conjunctivitis & $445(9.5)$ \\
\hline \multicolumn{2}{|l|}{ Main clinical conditions during hospitalisation } \\
\hline Duration of symptoms prior to admission & $7(4-10)$ \\
\hline $0-5$ days, $\mathrm{n}(\%)$ & $1730(37)$ \\
\hline$>5$ days, $\mathrm{n}(\%)$ & $2899(62.1)$ \\
\hline No registry, $\mathrm{n}(\%)$ & $41(0.9)$ \\
\hline NEWS score at admission & $3(2-4)$ \\
\hline Green, n (\%) & $3592(76.9)$ \\
\hline Yellow, n (\%) & $669(14.3)$ \\
\hline Red, n (\%) & $154(3.3)$ \\
\hline No registry, $\mathrm{n}(\%)$ & $255(5.5)$ \\
\hline CALL score on admission & $7(4-8)$ \\
\hline Steroid treatment at hospitalisation, n (\%) & $2057(44.1)$ \\
\hline High-flow nasal cannula requirement, n (\%) & $710(15.2)$ \\
\hline ICU admission, $\mathbf{n}(\%)$ & $216(4.6)$ \\
\hline Invasive mechanical ventilation requirement, $\mathbf{n}(\%)$ & $212(4.5)$ \\
\hline ICU duration days, & $8(5-14)$ \\
\hline Hospitalisation stay, days & $8(6-12)$ \\
\hline \multicolumn{2}{|l|}{ Outcome, n (\%) } \\
\hline Discharge & $4642(99.4)$ \\
\hline Referred & $28(0.6)$ \\
\hline \multicolumn{2}{|l|}{ Laboratory results during hospitalisation } \\
\hline Haemoglobin $(\mathrm{mg} / \mathrm{dL})$ & $13.9(12.8-14.9)$ \\
\hline Low haemoglobin (<12.5 mg/dL) & $856(18.3)$ \\
\hline D-dimer $(\mathrm{ng} / \mathrm{mL})$ & $540(340-1010)$ \\
\hline \multicolumn{2}{|l|}{ D-dimer categories, n (\%) } \\
\hline Normal level & $2028(43.4)$ \\
\hline 500 to $1000 \mathrm{ng} / \mathrm{mL}$ & $934(20)$ \\
\hline$>1000$ to $<1500 \mathrm{ng} / \mathrm{mL}$ & $392(8.4)$ \\
\hline$\geq 1500 \mathrm{ng} / \mathrm{mL}$ & $614(13.2)$ \\
\hline Ferritin $(\mu \mathrm{g} / \mathrm{L})$ & $283.3(116.5-591.6)$ \\
\hline High level (>336.2 $\mu \mathrm{g} / \mathrm{L}), \mathrm{n}(\%)$ & $1456(31.2)$ \\
\hline
\end{tabular}


Lactic dehydrogenase (UI/L)

High level (>233 UI/L), n (\%)

Absolute lymphocytes $\left(\times 10^{3}\right.$ cells $\left./ \mu \mathrm{L}\right)$

$<1000\left(\times 10^{3}\right.$ cells $\left./ \mu \mathrm{L}\right), \mathrm{n}(\%)$

Glucose $(\mathrm{mg} / \mathrm{dL})$
$206(165-264)$

1435 (30.7)

$1267.2(861-1793.4)$

$1475(31.6)$

$126(101-167)$

$2498(53.5)$

Data are presented as median (interquartile range) unless otherwise stated.

CALL, comorbidity, age, lymphocyte count, and lactate dehydrogenase; ICU, intensive care unit; NEWS, National Early Warning Score 
Table 3 Results of bivariate and multivariate analysis

\begin{tabular}{|c|c|c|c|c|c|c|c|c|c|c|c|c|c|c|c|c|}
\hline & \multicolumn{2}{|c|}{ Neurological } & \multicolumn{2}{|c|}{ Mood disorders } & \multicolumn{2}{|c|}{ Systemic } & \multicolumn{2}{|c|}{ Respiratory } & \multicolumn{2}{|c|}{ Musculoskeletal } & \multicolumn{2}{|c|}{$\begin{array}{l}\text { Ears, nose, } \\
\text { and throat }\end{array}$} & \multicolumn{2}{|c|}{ Dermatological } & \multicolumn{2}{|c|}{ Gastrointestinal } \\
\hline & $\begin{array}{c}30 \\
\text { days }\end{array}$ & $\begin{array}{l}90 \\
\text { days }\end{array}$ & $\begin{array}{c}30 \\
\text { days }\end{array}$ & $\begin{array}{c}90 \\
\text { days }\end{array}$ & $\begin{array}{l}30 \\
\text { days }\end{array}$ & $\begin{array}{c}90 \\
\text { days }\end{array}$ & $\begin{array}{c}30 \\
\text { days }\end{array}$ & $\begin{array}{c}90 \\
\text { days }\end{array}$ & $\begin{array}{c}30 \\
\text { days }\end{array}$ & $\begin{array}{c}90 \\
\text { days }\end{array}$ & $\begin{array}{l}30 \\
\text { days }\end{array}$ & $\begin{array}{c}90 \\
\text { days }\end{array}$ & $\begin{array}{c}30 \\
\text { days }\end{array}$ & $\begin{array}{c}90 \\
\text { days }\end{array}$ & $\begin{array}{c}30 \\
\text { days }\end{array}$ & $\begin{array}{l}90 \\
\text { days }\end{array}$ \\
\hline & $(\mathrm{N}=934$ & $(\mathrm{N}=491)$ & $(\mathrm{N}=931$ & $\begin{array}{c}(\mathrm{N}=492 \\
)\end{array}$ & $(\mathrm{N}=828)$ & $(\mathrm{N}=379)$ & (N=933) & $(\mathrm{N}=491)$ & $(\mathrm{N}=930$ & $(\mathrm{N}=492$ & $(\mathrm{N}=752)$ & $(\mathrm{N}=331)$ & $(\mathrm{N}=932)$ & $(\mathrm{N}=491)$ & $(\mathrm{N}=932)$ & $(\mathrm{N}=348)$ \\
\hline $\begin{array}{l}\text { Sex } \\
\text { (Male vs } \\
\text { Female) }\end{array}$ & $\begin{array}{c}0.59 \\
(0.43-0 \\
.81)^{\star *}\end{array}$ & $\begin{array}{c}0.38 \\
(0.24-0 . \\
62)^{\star \star \star}\end{array}$ & $\begin{array}{c}0.57 \\
(0.41-0 \\
.78)^{\star *}\end{array}$ & $\begin{array}{c}0.42 \\
(0.25-0 \\
.70)^{* \star}\end{array}$ & $\begin{array}{c}0.85 \\
(0.62-1.1 \\
6)\end{array}$ & $\begin{array}{c}0.51 \\
(0.29-0.9 \\
0)^{*}\end{array}$ & $\begin{array}{c}0.54 \\
(0.39-0.76 \\
)^{\star * \star}\end{array}$ & $\begin{array}{c}0.73 \\
(0.42-1.2 \\
6)\end{array}$ & $\begin{array}{c}0.59 \\
(0.42-0 \\
.82)^{* *}\end{array}$ & $\begin{array}{c}0.50 \\
(0.30-0 \\
.84)^{* *}\end{array}$ & $\begin{array}{c}0.75 \\
(0.51-1.10)\end{array}$ & $\begin{array}{c}0.71 \\
(0.36-1.3 \\
7)\end{array}$ & $\begin{array}{c}0.27 \\
(0.18-0 . \\
41)^{\star \star \star}\end{array}$ & $\begin{array}{c}0.27 \\
(0.16-0 . \\
45)^{\star \star \star}\end{array}$ & $\begin{array}{c}0.69 \\
(0.41-1.1 \\
6)\end{array}$ & $\begin{array}{c}0.38 \\
(0.14-1.0 \\
1)\end{array}$ \\
\hline $\begin{array}{l}\text { Age (1 } \\
\text { year } \\
\text { increase) } \\
\text { Middle }\end{array}$ & $\begin{array}{c}1 \\
(0.99-1 \\
.01)\end{array}$ & $\begin{array}{c}1 \\
(0.98-1 . \\
01)\end{array}$ & $\begin{array}{c}1 \\
(0.99-1 \\
.01)\end{array}$ & $\begin{array}{c}0.98 \\
(0.97-1 \\
.00)\end{array}$ & $\begin{array}{c}0.99 \\
(0.98-1.0 \\
1)\end{array}$ & $\begin{array}{c}0.98 \\
(0.96-1.0 \\
1)\end{array}$ & $\begin{array}{c}0.99 \\
(0.98-1)\end{array}$ & $\begin{array}{c}0.99 \\
(0.97-1.0 \\
1)\end{array}$ & $\begin{array}{c}1 \\
(0.99-1 \\
.02)\end{array}$ & $\begin{array}{c}0.99 \\
(0.97-1 \\
.01)\end{array}$ & $\begin{array}{c}0.98 \\
(0.97-1.00)\end{array}$ & $\begin{array}{c}0.97 \\
(0.94-0.9 \\
9)\end{array}$ & $\begin{array}{c}0.99 \\
(0.98-1 . \\
00)\end{array}$ & $\begin{array}{c}0.98 \\
(0.96-1 \\
)\end{array}$ & $\begin{array}{c}0.99 \\
(0.97-1.0 \\
1)\end{array}$ & $\begin{array}{c}1 \\
(0.96-1.0 \\
5)\end{array}$ \\
\hline $\begin{array}{l}\text { school } \\
\text { (vs } \\
\text { elementar } \\
\text { y or less) }\end{array}$ & $\begin{array}{c}1.4 \\
(0.9-2 . \\
18)\end{array}$ & $\begin{array}{c}1.02 \\
(0.54-1 . \\
94)\end{array}$ & $\begin{array}{c}1.02 \\
(0.65-1 \\
.60)\end{array}$ & $\begin{array}{c}1.02 \\
(0.53-1 \\
.99)\end{array}$ & $\begin{array}{c}1.38 \\
(0.86-2.2 \\
2)\end{array}$ & $\begin{array}{c}1.19 \\
(0.53-2.6 \\
9)\end{array}$ & $\begin{array}{c}1.14 \\
(0.7-1.85)\end{array}$ & $\begin{array}{c}1.24 \\
(0.58-2.6 \\
5)\end{array}$ & $\begin{array}{c}1.09 \\
(0.68-1 \\
.74)\end{array}$ & $\begin{array}{c}1.13 \\
(0.57-2 \\
.26)\end{array}$ & $\begin{array}{c}1.09 \\
(0.63-1.88)\end{array}$ & $\begin{array}{c}1.64 \\
(0.65-4.1 \\
1)\end{array}$ & $\begin{array}{c}1.38 \\
(0.79-2 . \\
43)\end{array}$ & $\begin{array}{c}0.94 \\
(0.48-1 \\
85)\end{array}$ & $\begin{array}{c}1.17 \\
(0.53-2.6 \\
1)\end{array}$ & $\begin{array}{c}1.57 \\
(0.34-7.3 \\
4)\end{array}$ \\
\hline $\begin{array}{l}\text { High } \\
\text { school } \\
\text { (vs } \\
\text { elementar } \\
\text { y or less) }\end{array}$ & $\begin{array}{c}1.41 \\
(0.92-2 \\
.16)\end{array}$ & $\begin{array}{c}1.06 \\
(0.56-1 . \\
98)\end{array}$ & $\begin{array}{c}1.07 \\
(0.69-1 \\
.65)\end{array}$ & $\begin{array}{c}0.74 \\
(0.38-1 \\
.44)\end{array}$ & $\begin{array}{c}0.96 \\
(0.6-1.53 \\
)\end{array}$ & $\begin{array}{c}0.96 \\
(0.42-2.2 \\
1)\end{array}$ & $\begin{array}{c}1.5 \\
(0.94-2.4)\end{array}$ & $\begin{array}{c}1.53 \\
(0.72-3.2 \\
5)\end{array}$ & $\begin{array}{c}1.38 \\
(0.88-2 \\
.16)\end{array}$ & $\begin{array}{c}1.24 \\
(0.62-2 \\
.46)\end{array}$ & $\begin{array}{c}0.86 \\
(0.51-1.47)\end{array}$ & $\begin{array}{c}0.56 \\
(0.21-1.5 \\
3)\end{array}$ & $\begin{array}{c}1.43 \\
(0.83-2 . \\
46)\end{array}$ & $\begin{array}{c}0.94 \\
(0.48-1 \\
82)\end{array}$ & $\begin{array}{c}1.24 \\
(0.57-2.6 \\
9)\end{array}$ & $\begin{array}{c}0.87 \\
(0.18-4.2 \\
6)\end{array}$ \\
\hline $\begin{array}{l}\text { or higher } \\
\text { (vs } \\
\text { elementar } \\
\text { y or less) }\end{array}$ & $\begin{array}{c}1.22 \\
(0.78-1 \\
.92)\end{array}$ & $\begin{array}{c}1.53 \\
(0.81-2 . \\
89)\end{array}$ & $\begin{array}{c}0.97 \\
(0.61-1 \\
.53)\end{array}$ & $\begin{array}{c}0.83 \\
(0.42-1 \\
.62)\end{array}$ & $\begin{array}{c}1.55 \\
(0.96-2.5 \\
)\end{array}$ & $\begin{array}{c}1.19 \\
(0.52-2.7 \\
3)\end{array}$ & $\begin{array}{c}1.63 \\
(1-2.65)\end{array}$ & $\begin{array}{c}1.44 \\
(0.67-3.0 \\
7)\end{array}$ & $\begin{array}{c}0.92 \\
(0.57-1 \\
.48)\end{array}$ & $\begin{array}{c}0.86 \\
(0.43-1 \\
.75)\end{array}$ & $\begin{array}{c}1.11 \\
(0.64-1.91)\end{array}$ & $\begin{array}{c}1.52 \\
(0.59-3.8 \\
7)\end{array}$ & $\begin{array}{c}1.05 \\
(0.59-1 . \\
89)\end{array}$ & $\begin{array}{c}1.14 \\
(0.58-2 . \\
23)\end{array}$ & $\begin{array}{c}1.23 \\
(0.55-2.7 \\
6)\end{array}$ & $\begin{array}{c}2.18 \\
(0.47-10 . \\
11)\end{array}$ \\
\hline $\begin{array}{l}\text { Diabetes } \\
\text { mellitus } \\
\text { (vs non- } \\
\text { DM) }\end{array}$ & $\begin{array}{c}1.21 \\
(0.87-1 \\
.68)\end{array}$ & $\begin{array}{c}0.81 \\
(0.5-1.3 \\
)\end{array}$ & $\begin{array}{c}1.17 \\
(0.84-1 \\
.63)\end{array}$ & $\begin{array}{c}0.78 \\
(0.47-1 \\
.3)\end{array}$ & $\begin{array}{c}0.87 \\
(0.62-1.2 \\
4)\end{array}$ & $\begin{array}{c}1.06 \\
(0.59-1.9 \\
2)\end{array}$ & $\begin{array}{c}0.91 \\
(0.64-1.3)\end{array}$ & $\begin{array}{c}0.78 \\
(0.44-1.3 \\
8)\end{array}$ & $\begin{array}{c}1.17 \\
(0.83-1 \\
.64)\end{array}$ & $\begin{array}{c}0.65 \\
(0.38-1 \\
.09)\end{array}$ & $\begin{array}{c}1.02 \\
(0.68-1.52)\end{array}$ & $\begin{array}{c}0.71 \\
(0.36-1.4 \\
1)\end{array}$ & $\begin{array}{c}0.89 \\
(0.58-1 . \\
35)\end{array}$ & $\begin{array}{c}1.21 \\
(0.74-1 . \\
98)\end{array}$ & $\begin{array}{c}1.14 \\
(0.64-2.0 \\
4)\end{array}$ & $\begin{array}{c}0.79 \\
(0.27-2.3 \\
2)\end{array}$ \\
\hline $\begin{array}{l}\text { Hyperten } \\
\text { sion (vs } \\
\text { non-HT) }\end{array}$ & $\begin{array}{c}1.04 \\
(0.75-1 \\
.44)\end{array}$ & $\begin{array}{c}0.66 \\
(0.41-1 . \\
07)\end{array}$ & $\begin{array}{c}1.13 \\
(0.81-1 \\
.57)\end{array}$ & $\begin{array}{c}0.66 \\
(0.39-1 \\
.12)\end{array}$ & $\begin{array}{c}0.96 \\
(0.68-1.3 \\
7)\end{array}$ & $\begin{array}{c}0.75 \\
(0.4-1.41 \\
)\end{array}$ & $\begin{array}{c}1.14 \\
(0.81-1.62 \\
)\end{array}$ & $\begin{array}{c}1.39 \\
(0.8-2.43)\end{array}$ & $\begin{array}{c}1.16 \\
(0.83-1 \\
.63)\end{array}$ & $\begin{array}{c}0.94 \\
(0.55-1 \\
.58)\end{array}$ & $\begin{array}{c}1.15 \\
(0.77-1.73)\end{array}$ & $\begin{array}{c}0.72 \\
(0.36-1.4 \\
5)\end{array}$ & $\begin{array}{c}0.52 \\
(0.34-0 . \\
81)^{\star *}\end{array}$ & $\begin{array}{c}0.81 \\
(0.49-1 . \\
35)\end{array}$ & $\begin{array}{c}1.31 \\
(0.73-2.3 \\
4)\end{array}$ & $\begin{array}{c}0.39 \\
(0.11-1.3 \\
3)\end{array}$ \\
\hline $\begin{array}{l}\text { Obesity } \\
\text { (vs } \\
\text { normal } \\
\text { weight) }\end{array}$ & $\begin{array}{c}1.1 \\
(0.74-1 \\
.64)\end{array}$ & $\begin{array}{c}1.52 \\
(0.86-2 . \\
68)\end{array}$ & $\begin{array}{c}1.33 \\
(0.89-2 \\
.01)\end{array}$ & $\begin{array}{c}1.38 \\
(0.76-2 \\
.53)\end{array}$ & $\begin{array}{c}1.28 \\
(0.82-1.9 \\
8)\end{array}$ & $\begin{array}{c}1.03 \\
(0.49-2.1 \\
8)\end{array}$ & $\begin{array}{c}1.63 \\
(1.06-2.51 \\
)^{*}\end{array}$ & $\begin{array}{c}0.7 \\
(0.37-1.3)\end{array}$ & $\begin{array}{c}1.28 \\
(0.84-1 \\
.95)\end{array}$ & $\begin{array}{c}1.35 \\
(0.73-2 \\
.5)\end{array}$ & $\begin{array}{c}0.99 \\
(0.6-1.63)\end{array}$ & $\begin{array}{c}1.16 \\
(0.5-2.7)\end{array}$ & $\begin{array}{c}1.02 \\
(0.64-1 . \\
62)\end{array}$ & $\begin{array}{c}1.21 \\
(0.67-2 . \\
17)\end{array}$ & $\begin{array}{c}0.68 \\
(0.36-1.3 \\
1)\end{array}$ & $\begin{array}{c}1.51 \\
(0.42-5.4 \\
2)\end{array}$ \\
\hline $\begin{array}{l}\text { HFNC } \\
\text { requirem } \\
\text { ent (vs no } \\
\text { requireme } \\
\text { nt) }\end{array}$ & $\begin{array}{c}1.05 \\
(0.68-1 \\
.61)\end{array}$ & $\begin{array}{c}1.65 \\
(0.79-3 . \\
49)\end{array}$ & $\begin{array}{c}1.1 \\
(0.71-1 \\
.69)\end{array}$ & $\begin{array}{c}1.26 \\
(0.55-2 \\
.88)\end{array}$ & $\begin{array}{c}1.35 \\
(0.87-2.1 \\
)\end{array}$ & $\begin{array}{c}1.01 \\
(0.44-2.3 \\
5)\end{array}$ & $\begin{array}{c}1.53 \\
(0.98-2.41 \\
)\end{array}$ & $\begin{array}{c}1.11 \\
(0.45-2.7 \\
1)\end{array}$ & $\begin{array}{c}1.57 \\
(1.01-2 \\
.45)^{\star}\end{array}$ & $\begin{array}{c}1.32 \\
(0.56-3 \\
.13)\end{array}$ & $\begin{array}{c}1.28 \\
(0.79-2.09)\end{array}$ & $\begin{array}{c}0.34 \\
(0.11-1.0 \\
2)\end{array}$ & $\begin{array}{c}1.19 \\
(0.68-2 . \\
09)\end{array}$ & $\begin{array}{c}1.14 \\
(0.53-2 . \\
47)\end{array}$ & $\begin{array}{c}0.74 \\
(0.33-1.6 \\
4)\end{array}$ & $\begin{array}{c}0.39 \\
(0.04-3.8 \\
2)\end{array}$ \\
\hline $\begin{array}{l}\text { IMV (vs } \\
\text { no } \\
\text { requireme } \\
\text { nt) } \\
\text { Dexamet }\end{array}$ & $\begin{array}{c}1.69 \\
(0.84-3 \\
.41)\end{array}$ & $\begin{array}{c}0.96 \\
(0.34-2 . \\
74)\end{array}$ & $\begin{array}{c}1.73 \\
(0.86-3 \\
.51)\end{array}$ & $\begin{array}{c}1.08 \\
(0.35-3 \\
.33)\end{array}$ & $\begin{array}{c}1.34 \\
(0.66-2.7 \\
4)\end{array}$ & $\begin{array}{c}0.4 \\
(0.1-1.64 \\
)\end{array}$ & $\begin{array}{c}1.12 \\
(0.55-2.29 \\
)\end{array}$ & $\begin{array}{c}0.42 \\
(0.12-1.4 \\
7)\end{array}$ & $\begin{array}{c}0.7 \\
(0.33-1 \\
.46)\end{array}$ & $\begin{array}{c}0.88 \\
(0.27-2 \\
.84)\end{array}$ & $\begin{array}{c}0.58 \\
(0.26-1.28)\end{array}$ & $\begin{array}{c}3.29 \\
(0.81-13 . \\
42)\end{array}$ & $\begin{array}{c}1.57 \\
(0.67-3 . \\
68)\end{array}$ & $\begin{array}{c}0.86 \\
(0.28-2 . \\
62)\end{array}$ & $\begin{array}{c}0.57 \\
(0.13-2.4 \\
5)\end{array}$ & $1(0-0)$ \\
\hline $\begin{array}{l}\text { hasone } \\
\text { at } \\
\text { hospital } \\
\text { (vs no } \\
\text { use) }\end{array}$ & $\begin{array}{c}0.88 \\
(0.63-1 \\
.22)\end{array}$ & $\begin{array}{c}0.87 \\
(0.53-1 . \\
42)\end{array}$ & $\begin{array}{c}0.91 \\
(0.65-1 \\
.28)\end{array}$ & $\begin{array}{c}0.62 \\
(0.36-1 \\
.05)\end{array}$ & $\begin{array}{c}1.09 \\
(0.76-1.5 \\
6)\end{array}$ & $\begin{array}{c}0.93 \\
(0.51-1.6 \\
8)\end{array}$ & $\begin{array}{c}0.68 \\
(0.47-0.97 \\
)^{*}\end{array}$ & $\begin{array}{c}0.61 \\
(0.34-1.1)\end{array}$ & $\begin{array}{c}0.68 \\
(0.48-0 \\
.98)^{\star}\end{array}$ & $\begin{array}{c}0.63 \\
(0.36-1 \\
.08)\end{array}$ & $\begin{array}{c}1.13 \\
(0.74-1.73)\end{array}$ & $\begin{array}{c}1.1 \\
(0.57-2.1 \\
2)\end{array}$ & $\begin{array}{c}0.64 \\
(0.42-0 . \\
97)^{\star}\end{array}$ & $\begin{array}{c}1.51 \\
(0.91-2 . \\
51)\end{array}$ & $\begin{array}{c}0.98 \\
(0.56-1.7 \\
1)\end{array}$ & $\begin{array}{c}0.46 \\
(0.16-1.3 \\
5)\end{array}$ \\
\hline
\end{tabular}




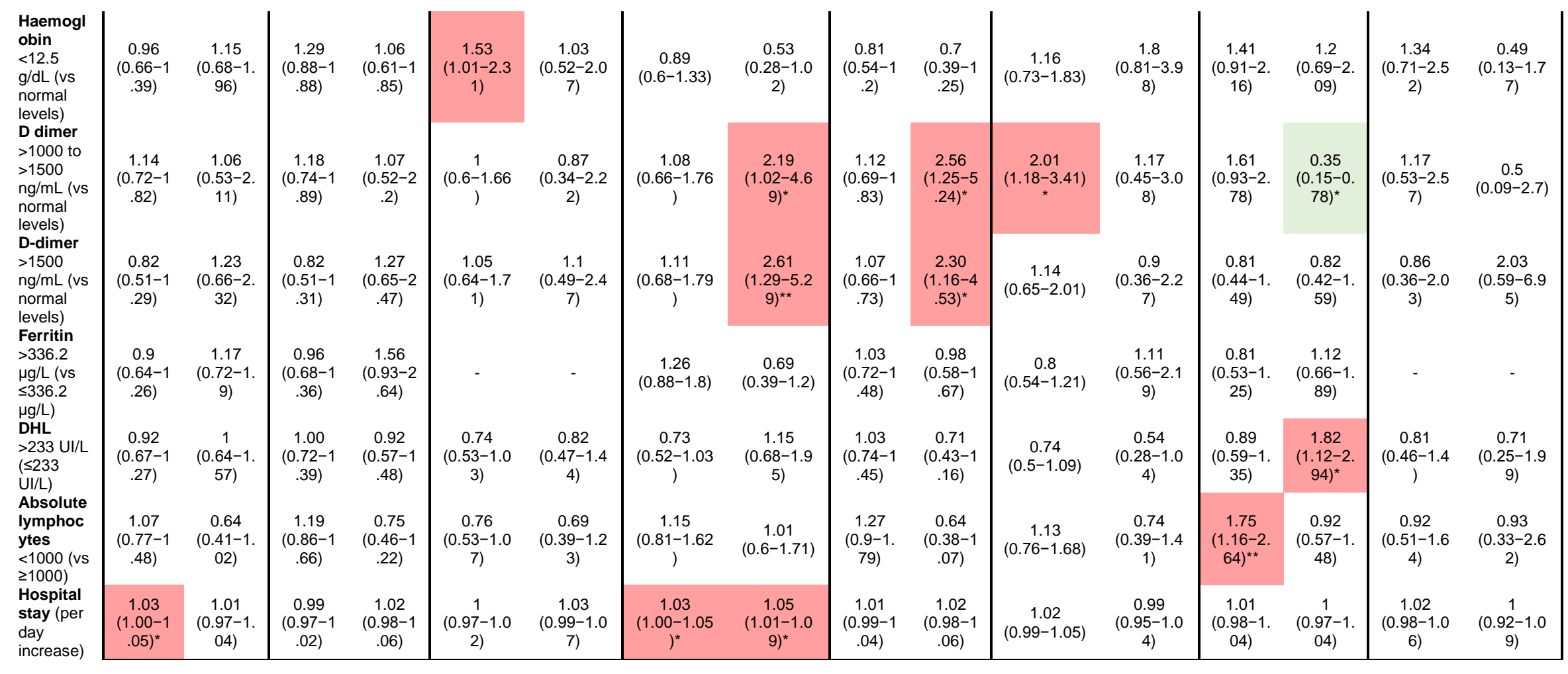

${ }^{*} p<0.05,{ }^{* *} p<0.01,{ }^{* * *} p<0.001$

Red cells indicate a higher association. Green cells indicate a lower association.

HFNC, high flow nasal cannula 


\section{Supplementary Information}

Supplementary Text 1. Patient questionnaire survey

Supplementary Figure 1. Symptom cluster descriptions

Supplementary Figure 2. Forest plots of background characteristics and laboratory values during hospitalisation stratified by the four main symptom clusters (a) neurological; (b) mood disorders; (c) musculoskeletal disorders; and (d) dermatological $\mathrm{Cl}$, confidence interval; HFNC, high flow nasal cannula; IMV, invasive mechanical ventilation; $\mathrm{LDH}$, lactate dehydrogenase; OR, odds ratio 